\title{
ANALISIS IMPLEMENTASI ENTREPRENEURSHIP DI KALANGAN SANTRI
}

\author{
Mustaqim \\ Suhadi \\ Jurusan Syariah, Sekolah Tinggi Agama Islam Negeri Kudus \\ (suhadialpati@gmail.com)
}

\begin{abstract}
Abstrak
Penelitian ini bertujuan untuk menganalisis implementasi entrepreneurship di Pondok Pesantren serta cara mengatasi kendala yang dihadapi dalam implementasi tersebut. Penelitian ini menggunakan metode field research (penelitian lapangan) yang disajikan secara diskriptif kualitatif.

Hasil Penelitian menunjukkan bahwa implementasi entrepreneurship di pondok pesantren khususnya di Ma'hadul Ulum Asy-Syar'iyyah Sarang Rembang berjalan dengan baik. Tujuan yang ditetapkan dalam implementasi tersebut adalah tercapainya santri yang dapat menyeimbangkan kepentingan kehidupan dunia dan akhirat. Kendala dalam penerapan entrepreneurship di Pondok pesantren pada umumnya adalah kesulitan dalam pengaturan jam pelatihan yang serngkali berbenturan dengan jam ngaji santri.

Hasil penelitian ini diharapkan akan menjadi bahan informasi dan masukan bagi mahasiswa, tenaga pengajar, peneliti dan semua pihak yang terkait dengan pemberian motivasi kepada rekan-rekan santri agar senantiasa meningkatkan kualitas kehidupannya dengan pelaksanaan wirausaha pada masa yang akan datang.
\end{abstract}

Kata Kunci: pesantren, entrepreneurship, santri

\section{A. Latar Belakang Masalah}

Unsur sumber daya manusia meliputi kemampuan- kemampuan (Capabilities), sikap (attitudes), nilai-nilai (values), kebutuhan- kebutuhan (needs) dan karakteristikkarakteristik demografisnya (penduduk). Unsur-unsur sumber daya manusia tersebut sangat dipengaruhi oleh lingkungan sekitarnya. Seperti norma-norma dan nilai-nilai masyarakat. Tingkat pendidikan dan peluang-peluang yang tersedia. Unsur-unsur tersebut pula gilirannya akan mempengaruhi peranan dan perilaku manajer dalam organisasi. Orang-orang dan organisasi dapat dibedakan satu dengan yang lainnya berdasarkan variabel-variabel tersebut. ${ }^{1}$

Seorang wirausahawan adalah pribadi yang mandiri dalam mengejar prestasi, ia berani mengambil resiko untuk mulai mengelola bisnis demi mendapatkan laba karena itu dia lebih memilih menjadi pemimpin dari pada menjadi pengikut. Untuk itu seorang wirausahawan memiliki rasa percaya diri yang kuat dan mempertahankan diri ketika menghadapi tantangan pada saat merintis usaha

\footnotetext{
${ }^{1}$ Fanstino Cardoso Gomes, Manajemen Sumber Daya Manusia. ANDI. Yogyakarta. 2003. hlm. 26
}

BISNIS, Vol. 2, No. 1, Juni 2014 
bisnis. Dalam menghadapi berbagai permasalahan, seorang wirausahawan senantiasa dituntut untuk kreatif. Dia mengetahui cara mencapai tujuan yang direncanakan, dan mampu berkonsentrasi serta berinisiatif memanfaatkan pengetahuan dan pengalaman untuk mengatur langkah sesuai dengan rencana yang telah dibuat menuju target.

Ada beberapa peluang dan tantangan dalam wirausaha yang berlandaskan pada nilai-nilai Islam, sifat dasar ajaran islam yang sangat mendorong umatnya untuk berusaha sendiri, kiranya bisa disebut sebagai peluang yang terbesar. Bila itu diwujudkan resultannya adalah berupa munculnya kelompok wirausahawan muslim yang kelak bila dikembangkan secara terus menerus bisa menjadi networking.

Pengalaman membuktikan bahwa salah satu faktor penentu keberhasilan usaha adalah koneksi dan jaringan usaha. Dengan adanya jaringan wirausahawan muslim, berbagai usaha bersama bisa dilakukan. Akan tetapi, untuk menjadi wirausahawan yang berhasil, bahkan untuk memulai usaha sendiri saja, sejumlah tantangan telah menghadang, tantangan internal berupa semangat atau etos wirausaha, lalu keahlian di bidang menejemen (produksi, pemasaran, dan keuangan) maupun pengembangan kepribadian wirausahawan (kreasi, inovasi, negoisasi, dan sebagainya) serta modal yang utama berkaitan dengan usaha itu (misalnya tentang riba, akad syarikah dan sebagainya).

Ketika praktik bisnis tak lagi mengenal etika, wirausahawan muslim yang ingin konsisten memegang syariah akan menghadapi tantangan yang berat. Disamping itu, tantangan juga datang dari regulasi ekonomi pemerintah, misalnya menyangkut kredit (yang ribawi) atau perizinan yang berbelit-belit sehingga membuka peluang praktik riswah (sogok-menyogok) yang sangat dicela Islam. Semua ini bisa mengendurkan berwirausaha.

Tantangan internal bisa diatasi dengan misalnya mengadakan pelatihan kewirausahaan. Dalam pelatihan diberikan materi untuk mendorong motivasi berusaha, peningkatan kemampuan manajerial, serta pengembangan kepribadian wirausahawan muslim. Juga diberikan materi tentang hokum islam memyangkut masalah ekonomi dan praktik bisnis dalam islam sementara tantangan eksternal diatasi dengan mengubah regulasi, ekonomi agar sesuai dengan syari'ah dan menjalin jaringan wirausaha muslim sebagaimana telah disebut di atas, termasuk mengadakan lembaga keuangan syariah untuk memenuhi modal non ribawi bagi para wirausahawan muslim.

Entrepreunership memang harus bisa ditanamkan dalam diri setiap orang. Termasuk kalangan santri di pondok pesantren yang ada ini juga merujuk pada sosok nabi Muhammad SAW, yang juga adalah sosok dengan jiwa entrepreunership yang tinggi. Terlebih dalam kemampuannya berdagang ini juga yang dikatakan bahwa jiwa tersebut memang sudah melekat dalam diri umat Islam.

Muhammad Jazuli mengungkapkan, melihat pentingnya semangat entrepreunership di kalangan santri, maka sudah saatnya para santri diberikan bekal kemandirian. "semua orang mengetahui institusi pesantren adalah sebuah lembaga yang independen. Sebuah lembaga yang mengajarkan kemandirian kepada para santri di dalamnya, jadi tidak salah bila konsep ini mulai masuk di kurikulum pesantren", ungkapnya. 
Tidak heran jika saat ini, banyak sekali usaha produktif yang sangat berkembang di lingkungan pesantren. Karena pesantren memiliki unit usaha di dalamnya, dimana peputaran yang berjalan ratusan sampai dengan milyaran rupiah. Lihat saja pesantren Gontor, pesantren sidogiri Pasuruan, atau pesantren Darun Najah Jakarta. Mereka memiliki badan usaha yang bergerak secara mandiri di dalamnya ini dalam menjalankan roda perekonomian Pesantren. ${ }^{2}$

Sebagaimana yang diharapkan, seorang santri bisa mandiri. Dan kemandiriannya itu bisa diwujudkan dengan menjadi seorang entrepreunership sejati. Sehingga mereka tidak terikat pada birokrasi kepemerintahan. Kemandirian ini bisa diwujudkan dengan memperdayakan lingkungan sekitarnya, karena dunia pesantren sebenarnya telah mendidik santrinya untuk hidup mandiri dan berdikari. Sudah saatnya ketika terjun ke masyarakat, mereka bisa hidup secara mandiri.

Pesantren merupakan lembaga pendidikan Islam, yang penyelenggaraan pendidikannya secara umum dengan cara non klasikal, yaitu seorang kiai yang mengajarkan ilmu agama Islam kepada santri-santri berdasarkan kitab-kitab yang ditulis dalam bahasa arab oleh ulama-ulama Arab abad pertengahan. Para santri biasanya tinggal dalam pondok (asrama) dalam pesantren tersebut. Kiai sebagai seorang ahli agama Islam, mengajarkan ilmunya kepada santri dan biasanya sekaligus pemimpin dan pemilik pesantren tersebut. Selama ini memang belum pernah ada rumusan tertulis mengenai tujuan pendidikan pesantren. Minimal para kiai mempersiapkan para santrinya sebagai tenaga siap pakai tanpa harus bercita-cita menjadi pegawai negeri. Namun lebih jauh para santri sebagian besar menjadi pemuka masyarakat yang diidamidamkan oleh masyarakat. ${ }^{3}$ Konsep ini telah dijalankan seperti di Pondok pesantren Al-Ma'hadul Ulum Asy-Syar'iyyah Karangmangu Sarang Rembang dan banyak pesantren yang lain agar para santri mempunyai skill yang akan dibawanya nanti, setelah lulus dari Pondok pesantren.

Di sinilah pertarungan budaya lokal dan gerusan arus global akan sangat menjadi niscaya ketika unsur lokalitas menampakkan diri ke permukaan. Sebagai lembaga tafaqquh fid din, pesantren yang tersebar luas di Indonesia sejak munculnya hingga sekarang memang mempunyai daya tarik, baik dari sosok luarnya, kehidupan sehari-hari, potensi dirinya, isi pendidikannya, maupun sistem dan metodenya, semua menarik untuk dikaji. Tidak aneh bila belakangan ini banyak ilmuwan dari kalangan Islam, baik dalam maupun luar negeri, mengarahkan penelitiannya pada pesantren.

Internalisasi nilai moralitas oleh pesantren sungguh sangat menarik untuk dikaji. Pendidikan entrepreneurship di pesantren dilaksanakan dengan maksud agar santri/peserta didik tidak ketinggalan zaman dalam hal-hal baru dan siap untuk menjadi agent of change.

Pesantren dan santri bagian dari anggota masyarakat tentu saja tidak akan bisa lepas dari pengaruh budaya yang berkembang di masyarakatnya. Kemajuan teknologi komunikasi dan informasi telah membuka tabir dan misteri

\footnotetext{
${ }^{2}$ Muhammad Jazuli, Tanamkan Jiwa Entrepreunership, Metro KUDUS, 20/08/2012.

${ }^{3}$ Binti Maunah, Tradisi Intelektual Santri, Teras, Yogyakarta, 2009, hlm, 25.
} 
kehidupan dengan cepat. Transparansipun dituntut dalam berbagai dimensi kehidupan. ${ }^{4}$

\section{B. Entrepreneurship}

\section{a. Pengertian Entrepreneurship}

Kata entrepreneur adalah padanan dari kata entrepreneur (bahasa Inggris) yang berasal dari bahasa perancis 'entreprendre' yang sudah di kenal sejak abad ke -17. The concise oxford French dictionary mengartikan entreprendre sebagai to undertake (menjalankan, melakukan, berusaha), to set about (memulai, menentukan), dan to attempt (mencoba, berusaha) kata 'entrepreneur' atau 'wirausaha' dalam bahasa Indonesia merupakan gabungan dari wira (gagah, berani, perkasa) dan usaha (bisnis) sehingga istilah entrepreneur dapat diartikan sebagai orang yang berani atau perkasa dalam usaha/ bisnis. ${ }^{5}$

Entrepreneurship adalah segala hal yang berkaitan dengan sikap, tindakan, dan proses yang dilakukan oleh para enterprenuer dalam merintis, menjalankan, dan mengembangkan usaha mereka. Entrepreneurship sering juga dikaitkan dengan adanya pendatang baru dalam dunia bisnis. Entrepreneurship tidaklah dimulai dengan menjual produk dan jasa, tetapi dimulai dengan adanya kesempatan atau peluang yang berasal dari lingkungan. faktor lingkungan itu terdiri dari faktor ekonomi, politik, hukum dan sosial. Kondisi ekonomi makro yang baik dan sehat akan lebih memacu kegiatan entrepreneurship, demikian juga halnya dengan ekonomi global. Faktor politik dan hukum juga berpengaruh terhadap kegiatan entrepreneurship dalam bentuk regulasi dan kemudahan berusaha. Faktor sosial juga berpengaruh terhadap entrepreneurship, baik dari sistem masyarakat, jaringan, maupun pola pikir yang terbentuk di dalamnya.

\section{b. Karakteristik Entreprenuer}

Sejarah Islam mencatat bahwa Entrepreneurship telah dimulai sejak lama, pada masa Adam AS. Dimana salah satu anaknya Habil berwirausaha dengan bercocok tanam dan Qobil berwirausaha dengan menggembala hewan ternak. Banyak sejarah nabi yang menyebutkan mereka beraktivitas di kewirausahaan, sebagian dari mereka berwirausaha di sektor pertanian, peternakan, kerajinan dan bisnis perdagangan. Contoh yang paling nyata adalah Nabi Muhammad SAW, awalnya beliau terlibat di bisnis dengan memelihara dan menjual domba, kemudian membantu bisnis pamannya dan akhirnya me-manage bisnis Khadijah ra. ${ }^{6}$

Hands Scholhammer, seorang pendidik dengan pengalaman bertahun-tahun lamanya dalam bidang entrepreneurship yang telah mengklasifikasi aneka macam cara yang dapat terjadi atau terbentuknya pada organisasi-organisasi. Ia juga menyatakan bahwa strategi-strategi korporat yang dirumuskan untuk menunjang masing- masing pendekatan, akan mempengaruhi cara-cara bagaimana

\footnotetext{
${ }^{4}$ Moh Roqib, Ilmu Pendidikan : Pengembangan Pendidikan Integratif di Sekolah, Keluarga dan Masyarakat, LkiS, Yogyakarta, 2009, hlm. 158.

${ }^{5}$ Arman Hakim Nasution, Entrepreneurship, Membangun Spirit Teknopreneurship, CV. ANdi Offset, Yogyakarta, 2007, hlm.2

${ }^{6}$ Entrepreneurship dalam Islam, http://omahkeong.blogspot.com/2009/12/ entrepreneurship-dalamislam.html, 30/06/2014
} 
perusahaan akan mempromosikan dirinya untuk kegiatan pertumbuhan. Adapun lima macam klasifikasinya sebagai berikut:

1) Administrative Entrepreneurship

Manajemen R\&D sangat didekati pada gaya administratif ini. Hal khusus yang menyebabkan bahwa R\&D entrepreneurial mungkin merupakan suatu kondisi pemikiran (a state of mind) yang merupakan sebuah falsafah korporat gabungan para secara enthusias, menuju ke prestasi yang lebih baik ${ }^{7}$.

2) Opportunistic Entrepreneurship

Ikatan-ikatan struktural formal dilepaskan sewaktu para ahli-ahli produk berupaya untuk memanfaatkan peluang-peluang unik. Perspektif R\&D tradisional dihindari, dan diberi kebebasan pada individu-individu untuk mengembangkan ide-ide di dalam dan di luar organisasi mereka.

3) Acquisitive Entrepreneurship

a. Pendekatan akuisitif, mendorong para manajer untuk melihat keluar untuk mencapai inovasi-inovasi yang dapat menyebabkan timbulnya pertumbuhan cepat dan laba besar.

4) Imitative Entrepreneurship

b. Kadang-kadang ia dinyatakan sebagai "spionase perusahaan" (corporate espionagae). Imitative Entrepreneurship memanfaatkan ide-ide dan invensi perusahaan orang lain.

5) Incubative Entrepreneurship

c. Setelah perusahaan mencapai produk-produk atau paten- paten baru, maka mereka perlu mengalokasi sumber-sumber daya untuk mengkomersialisasi hal-hal tersebut. Kegiatan ini di awali dengan fokus perhatian yang insentif terhadap pengembangan.

Setelah diterapkannya elemen-elemen penting di atas, diharapkan para santri bisa berjiwa entrepreneur. Kafrawi mengatakan, tidak mengherankan apabila dari kalangan pesantren banyak pula tumbuh usahawan-usahawan. Hanya saja usahawan itu, tumbuh dan mencari jalan sendiri. Mereka umumnya tumbuh otodidak, yang tidak mendekati masalah dari segi ilmiah tetapi berdasarkan intuisi. Karena memang pendidikan kewiraswastaan (entrepreneurship) di pesantren tersebut tidak terkoordinir dan tidak direncanakan bahkan untuk itu tidak dibuat kerangkanya. ${ }^{8}$

\section{c. Orientasi Entrepreneur}

Untuk mengukur orientasi entrepreneurial yaitu persepsi manajerial, perilaku perusahaan, dan alokasi sumber daya. Entrepreneur tidak menganggap diri mereka sebagai pengambil resiko, tetapi sering memandang keadaan bisnis secara lebih positif dibandingkan dengan yang bukan entrepreneur. Orientasi entrepreneurial berhubungan dengan variabel lingkungan internal maupun eksternal.

\footnotetext{
${ }^{7}$ Winardi menjelaskan R\&D atau "research and development" yaitu pendekatan tradisional untuk menciptakan produk-produk atau proses baru di dalam lingkungan korporasi. Dan Sugiyono, Metode Penelitian Pendidikan - pendekatan Kualitatif, Kuantitatif, dan R\&D, Alfabeta, Bandung, 2010, hlm. 407

${ }^{8}$ Kafrawi, Pembaharuan Sistem Pendidikan Pondok Pesantren Sebagai Usaha Peningkatan Prestasi Kerja dan Pembinaan Kesatuan Bangsa, Cemara Indah, Jakarta, 1978, hlm. 66
} 
Lyon, Lumpkin, dan Dess memunculkan 5 dimensi orientasi entrepreneurial (dari kata Entrpreneurial orientation), yaitu otonomi, sikap inovatif, pengambilan resiko,sikap proaktif, dan sikap bersaing secara agresif. Orientasi entrepreneurial berbeda dengan entrepreneurship. Pengertian entrepreneurship lebih merujuk kepada pendatang/ pemain baru dalam bisnis, sedangkan entrepreneurial lebih mengarah kepada proses, yaitu bagaimana entrepreneurship tersebut dijalankan yang mencakup metode, praktek, dan gaya pengambilan keputusan untuk bertindak secara entrepreneurial.

Orientasi entrepreneurial sangat dipengaruhi oleh faktor budaya. Kemampuan entrepreneurship suatu negara pada kombinasi yang sangat istemewa dari faktor budaya, misalnya nilai, sikap, perilaku, norma, serta pranata lainnya yang dapat memperkuat orientasi entrepreneurial. Penjelasan dari kelima dimensi orientasi entrepreneurial serta kaitannya denagan budaya pada suatu Negara dapat dibahas secara singkat sebagai berikut:

1. Otonomi

Katalis yang dapat mendorong aktivitas entrepreneurial adalah semangat dan kebebasan untuk mandiri dalam mendirikan usaha - usaha baru sehingga dimensi otonomi tersebut merupakan bagian sangat penting dari orientasi entrepreneurial. Guna menjaga dimensi otonomi agar tetap kuat, para entrepreneur harus bekerja pada lingkungan budaya yang mampu mendukung mereka untuk bertindak secara bebas (otonomi) guna menjaga kendalo terhadap pekerja/karyawan serta mencari semua peluang tanpa hambatan yang berarti dari masyarakat.

2. Kreatif berinovasi

Inovasi yang kreatif berperan besar dalam entrepreneurship.walaupun para entrepreneur beroperasi dalam lingkungan yang mendukung tumbuhnya ide/gagasan baru, eksprementasi, solusi baru, atau proses kreatif, tetapi mereka tetap membutuhkan sikap inovatif sebagai dimensi yang sangat penting untuk menjalankan usaha. Budaya inovatif kreatif yang tinggi akan memberikan peluang yang lebih besar dalam perkembangan teknologi baru, produk baru, jasa baru, atau proses baru di dalam masyarakat yang bersangkutan,

3. Pengambilan Resiko

Hal yang berkaitan dengan entrepreneurship adalah keinginan dan keberanian dalam pengambilan resiko.para individu yang siap menerima ketidakpastian dan resiko sering dianggap sebagai orang yang mampu bekerja sendiri atau entrepreneur. Sikap pengambilan resiko merupakan komponen yang penting dalam orientasi entrepreneurial. Lingkungan budaya yang dapat memacu sikap berani dalam menghadapi resiko akan lebih banyak lagi melahirkan para entrepreneur baru yang terus berkelanjutan,

4. Proaktif

Budaya yang mendukung sikap proaktif dicirikan oleh adanya dukungan terhadap kegiatan entrepreneurial untuk bertindak antisipatif terhadap segala peluang/ kesempatan serta parsitipasi dalam pasar yang lama atau baru. Para individu yang proaktif akan melakukan semua hal untuk mewujudkan konsep mereka serta memperoleh manfaat keunggulan sebagai orang pertama ( perintis jalan ) yang merebut setiap peluang. 


\section{Bersaing Agresif}

Lingkungan budaya yang dapat menumbuhkan semangat berprestasi dengan menyongsong setiap pesaing yang ada dengan cara memperbaiki posisi mereka dalam peta persaingan adalah bagian penting untuk menumbuhkan sikap bersaing agresif. Hal tersebut penting karena masih banyak perusahaan yang gagal daripada yang berhasil dalam tahap awal perkembangannya, sekaligus juga sebagai faktor kritis dalam kelangsungan hidup setiap perusahaan.

"It is my great honor to receive this prize. I couldn't have had this opportunity without the great support of the people of my company and all those whom concerned. At this award, we will continue trying our best to improve, and hopefully to win upper prize. Thank you very much indeed."

Menggunakan model Hofstede dan Trompenaars ${ }^{9}$ ditemukan bahwa lingkungan budaya suatu Negara yang rendah jarak kuasanya, lemah dalam penghindaran ketidakpstian, sikap maskulinitas, indivudualistis, orientasi hasil/prestasi, serta universalitas akan cenderung memiliki nilai orientasi entrepreunial yang tinggi yang dicirikan oleh adanya otonomi, sikap proaktif, sikap bersaing agresif, sikap inovatif, dan sikap pengambilan resiko. Nilai EO (Entrepreneurial Prientation = orientasi entrepreneurial) yang tinggi akan mengarah kepada peningkatan semangat entrepreneurship dan kemapuan bersaing secara global.

Beberapa dimensi budaya yang dimaksud adalah power distance, uncertainty avoidance, individualism, masculinity, achievement, dan universalism. Penjelasan singkat mengenai keenam dimensi budaya tersebut adalah sebagai berikut:

a. Power distance (jarak kuasa) adalah derajat toleransi untuk hierarki atau hubungan yang tidak sama (tinggi berarti derajat toleransi yang besar dalam hubungan yan berbeda, rendah berarti toleransi yang rendah dalam hubungan yang berbeda).

b. Uncertainty avoidance adalah derajat penerimaan terhadap ketidakpastian atau kemauan mengambil resiko (kuat berarti penerimaan yang kecil untuk ketidakpastian atau resiko, lemah berarti penerimaan yang besar terhadap ketidakpastian atau resiko).

c. Individualism adalah derajat pencapaian yang diraih berdasarkan prestasi individu (individualism berarti derajat pencapaian individual yang tinggi, kolektivisme berarti lebih ditentukan oleh hasil kerja bersama).

d. Masculinity, adalah derajat penekanan terhadap unsur materialism (maskulinitas berarti derajat penekanan unsur materi yang besar, feminimitas berarti penekanan pada unsur harmoni dan hubungan baik).

e. Achievement, adalah penggambaran mengenai bagaimana kekuasaan dan status diperoleh (berarti kekuasaan dan status yang diperoleh melalui persaingan dan kerja keras; berarti kekuasaan dan status yang diperoleh karena bawaan lahir, usia, atau gender).

f. Universalism adalah gambaran norma untuk mengatur perilaku masyarakat (universalisme berarti kode etik dan hokum yang berlaku untuk semua

${ }^{9}$ Journal of World Business, 2000, Vol. 35, pp. 401-417. 
pihak, partikularisme berarti ada beberapa individu yang menikmati hak istimewa karena statusnya).

Tabel 1. Pembentuk Orientasi Entrepreneur dan Spirit Entrepreneur

\begin{tabular}{|c|c|c|}
\hline $\begin{array}{l}\text { Pembentuk } \\
\text { Orientasi } \\
\text { Entrepreneur }\end{array}$ & $\begin{array}{l}\text { Pembentuk Spirit } \\
\text { Entrepreneurial }\end{array}$ & Keterangan \\
\hline $\begin{array}{l}\text { Otonomi } \\
\text { (kemandirian) }\end{array}$ & $\begin{array}{l}\text { Locus of control internal } \\
\text { Kemandirian }\end{array}$ & $\begin{array}{l}\text { Jiwa/spirit entrepreneurial } \\
\text { dibentuk oleh sikap } \\
\text { kemandirian dan kendali } \\
\text { diri (locus of control) } \\
\text { internal yang mantap }\end{array}$ \\
\hline Sikap inovatif & $\begin{array}{l}\text { Kreativitas dan } \\
\text { inovasi }\end{array}$ & $\begin{array}{l}\text { Kreativitas dan inovasi } \\
\text { merupakan factor penemu } \\
\text { keberhasilan dalam dunia } \\
\text { bisnis }\end{array}$ \\
\hline Sikap proaktif & Perencanaan & $\begin{array}{l}\text { Adanya perencanaan } \\
\text { dan sikap proaktif akan } \\
\text { menjamin kesuksesan dan } \\
\text { keunggulan dalam banyak } \\
\text { aspeknya }\end{array}$ \\
\hline $\begin{array}{l}\text { Pengambilan } \\
\text { Resiko }\end{array}$ & $\begin{array}{l}\text { Pengambilan } \\
\text { resiko } \\
\text { moderat }\end{array}$ & \begin{tabular}{ll} 
Berani & \multicolumn{2}{c}{ menghadapi } \\
resiko yang & telah \\
diperhitungkan adalah & ap cermat dan cerdas \\
sikap & dalam bersaing
\end{tabular} \\
\hline $\begin{array}{ll}\text { Sikap } & \text { Berani } \\
\text { Bersaing } & \end{array}$ & $\begin{array}{l}\text { Pengejaran prestasi } \\
\text { Agresif }\end{array}$ & $\begin{array}{l}\text { Pencapaian prestasi } \\
\text { dalam persaingan yang } \\
\text { makin ketat menjadi tujuan } \\
\text { utama para enterpreur. }\end{array}$ \\
\hline
\end{tabular}

Ada kesamaan ciri atau faktor antara jiwa/spirit entrepreneurial dengan orientasi entrepreneurial. Keenam dimensi jiwa/spirit entrepreneurial sangat besar peranannya dalam mempersiapkan para calon entrepreneur dari kalangan mahasiswa untuk memilih kerja mandiri ataupun menjadi professional / karyawan.

\section{d. Pentingnya kewirausahaan}

Pada awal abad 20, Entrepreneurship atau kewirausahaan menjadi satu kajian hangat karena perannya yang penting dalam pembangunan ekonomi adalah Schumpeter yang mengatakan bahwa jika suatu Negara ingin maju, jumlah entrepreunernya harus banyak. Entrepreneurship is driving force behind economic growth. Krizner mengatakan bahwa kewirausahaan merupakan bagian penting dalam pembangunan. 
Rasionalisasinya adalah jika seseorang memiliki kewirausahaan, dia akan memiliki karakteristik motivasi/mimpi yang tinggi (need of achievement), berani mencoba (risk taker) Innovative dan independence. Dengan sifatnya ini, dengan sedikit saja peluang dan kesempatan, dia mampu berubah menghadilkan sesuatu yang baru. Relasi baru akumulasi modal, baik berupa perbaikan usaha ini, akan menggerakkan material/bahan baku untuk "Berubah bentuk" yang lebih bernilai sehingga akhirnya konsumen mau membelinya. Pada proses ini akan terjadi pertukaran barang dan jasa, baik berupa sumber daya alam, uang, sumber daya social. Kesempatan maupun sumber daya manusia. Dalam ilmu ekonomi, jika terjadi hal demikian, itu berarti ada pertumbuhan ekonomi, dan jika ada pertumbuhan ekonomi berarti ada pembangunan.

Salah satu penyebab kegagalan dalam pencapaian pertumbuhan ekonomi dan pembangunan ekonomi suatu Negara karena tidak adanya entrepreneurship baik dalam level individu, organisasi dan masyarakat. Menurut ahli perilaku (behavioritas). entrepreneurship sangat berperan dalam kesuksesan seseorang. Seseorang yang memiliki kewirausahaan tinggi dan digabung dengan kemampuan manajerial yang memadai akan menyebabkan dia sukses dalam usahanya. Entrepreneurship juga berperan dalam mengembangkan seseorang sehingga memiliki keinginan untuk memaksimalkan economic achievement dan menyebabkan seseorang bisa tahan uji, bisa fleksibel, bisa dipercaya, bisa mengatasi masalah yang dihadapinya.

Wirausaha mencakup beberapa unsur penting yang satu dengan lainnya saling terkait, bersinergi, dan tidak terlepas satu sama lain, yaitu unsur daya pikir (kognitif), unsur ketrampilan (psikomotorik), unsur kewaspadaan dan/atau intuisi. ${ }^{10}$ Pertama, daya pikir, pengetahuan, kepandaian, intelektual, atau kognitif mencirikan tingkat penalaran, taraf pemikiran yang dimiliki seseorang. Daya pikir adalah juga sumber dan awal kelahiran kreasi dan temuan baru serta yang terpenting ujung tomba kemajuan suatu umat. Dalam pandangan Al-Baghdadi memang pemikiranlah yang secara sunnatullah mampu membangkitkan suatu umat sebab potensi bangkit dimiliki manusia manapun secara universal. ${ }^{11}$

Kedua, unsur keterampilan. Maksudnya mengandalkan berfikir saja belumlah cukup untuk dapat mewujudkan suatu karya nyata. Karya hanya terwujud jika ada tindakan. Keterampilan merupakan tindakan raga untuk melakukan suatu kerja. Dari hasil kerja itulah baru dapat diwujudkan suatu karya, baik berupa produk maupun jasa keterampilan dibutuhkan oleh siapa saja, Islam memberikan perhatian besar bagi pentingnya penguasahaan keahlian atau keterampilan. Penguasaan keterampilan yang serba material ini juga merupakan tuntutan yang harus dilakukan oleh setiap muslim dalam rangka pelaksanaan tugasnya. Secara normativ, terdapat nash dalam al-Qur'an dan hadits yang mengajurkan untuk mempelajari ilmu-ilmu pengetahuan umum atau keterampilan. ${ }^{12}$

Jika dicermati lebih lanjut, banyak pengusaha besar sukses ternyata hanya berlatar belakang pendidikan sekolah menengah dan juga hanya lulusan SD

\footnotetext{
${ }^{10}$ Orang terjun ke dunia usaha berkewajiban mengetahui hal-hal yang dapat mengakibatkan jual beli itu sah atau fasid.

${ }^{11}$ Muhammad Ismail Yusnanto, Menggagas Bisnis Islami. Gema Insani, Jakarta, 2002, hlm. 33-34.

${ }^{12}$ Dwi Swiknyo, Tarbiyah Finansial, Diva Press, Yogyakarta, 2009, hlm.13
} 
(Sekolah Dasar), namun kebanyakan dari pengusaha- pengusaha banyak yang SD (istilah Jawa : Sinau Dhewe) atau belajar sendiri/otodidak. Bagi seorang muslim, sikap mental maju pada hakikatnya merupakan konsekuensi dari tauhid dan buah dari kemuslimannya dalam seluruh aktivitas kesehariannya. Identitas itu tampak pada kepribadian seorang muslim yakni pada pola berpikir (aqliyyah) dan pola bersikapnya (nafisyyah) yang dilandaskan pada aqidah Islam. Di sini tampak jelas bahwa sikap mental maju sesungguhnya adalah buah dari hasil pola sikap yang didorong secara produktif oleh pola pikir Islami.

Keempat, unsur Intuisi. Intuisi atau juga dikenal sebagai feeling adalah sesuatu yang abstrak, sukar digambarkan, namun acapkali menjadi kenyataan jika dirasakan serta diyakini benar dan lalu diusahakan.

Perspektif Islam, intuisi dapat dinilai sebagai bagian lanjut dari pemikiran dan sikap mental maju yang telah dimiliki seorang muslim. Seorang muslim memang dituntut untuk mengaplikasikan pemahaman Islam dalam menjalankan kegiatan hidupnya. Proses aplikasi dapat dilakukan diantaranya dengan cara menumbuhkan kesadaran dan melatih kepekaan perasaan.

\section{Pondok Pesantren}

\section{a. Pengertian Pondok Pesantren}

Menurut Manfred Ziemek, sebagaimana dikutip oleh Wahjoetomo menyebutkan bahwa kata pondok berasal dari funduq (Arab) yang berarti ruang tidur atau wisma sederhana, karena pondok memang merupakan tempat penampungan sederhana bagi para pelajar yang jauh dari tempat asalnya. Sedangkan kata pesantren berasal dari kata santri yang diimbuhi awalan pe- dan akhiran -an yang berarti menunjukkan tempat, maka artinya adalah tempat para santri. Terkadang juga dianggap sebagai gabungan kata sant (manusia baik) dengan suku kata tra (suka menolong), sehingga kata pesantren dapat berarti tempat pendidikan manusia baik-baik. ${ }^{13}$

Sedangkan menurut Geertz, juga dikutip oleh Wahjoetomo, menjelaskan bahwa pengertian pesantren diturunkan dari bahasa India sastri yang berarti ilmuwan Hindu yang pandai menulis, maksudnya pesantren adalah tempat bagi orang-orang yang pandai membaca dan menulis. Geertz menganggap bahwa pesantren dimodifikasi dari pura Hindu.

Menurut Zamahsari Dhofier, ciri khas atau ideologi pendidikan pesantren sangat dipengaruhi oleh ideologi pendiri pesantren tersebut yang berfaham ahlussunnha wal jamaah. Dan dalam kajian hukum- hukum Islam mengacu pada empat madzhab, dan penggunaan madzhab syafi'i sangat kentara dalam pesantren hal tersebut dapat dilihat dari kitab-kitab / kurikulum yang digunakan. Hal tersebut tidak bisa lepas dari faktor sejarah penyebaran Islam di Indonesia bahwa para Walisongo dalam praktek-praktek keagamaan "ibadah" menggunakan Madhab Syafi' i. ${ }^{14}$

Kemudian dipertegas lagi bahwa pada umumnya para kiai dibesarkan dan dididik dalam lingkungan pesantren yang memegang teguh faham Islam

\footnotetext{
${ }^{13}$ Wahjoetomo, Perguruan Tinggi Pesantren, Cet. I, Gema Insani Pers, Jakarta, 1997, hlm. 70

${ }^{14}$ Zamahsyari Dhofier, Tradisi Pesantren Studi tentang Pandangan Hidup Kiyai, AP3DS, Jakarta, 1984, hlm. 149
} 
tradisional. Ketegasan para kiai memilih faham Islam tradisional ini secara jelas dapat dibuktikan dari kitab-kitab yang diajarkan dipesantren, hampir semua pondok pesantren yang ada di jawa merupakan pengikut faham ahlussunnah wal jama'ah dengan bepegang kepada tradisi sebagai berikut:

1) Dalam bidang hukum-hukum Islam menganut ajaran-ajaran dari salah satu madzhab empat. Dalam praktek, para kiai adalah penganut kuat dari madzhab syafi'i.

2) Dalam soal-soal tauhid, menganut ajaran Imam abu Hassan dan Imam Abu Mansur al-Maturidi.

3) Dalam bidang tasawwuf menganut dasar-dasar ajaran Imam Abu Qosim AlJunaid.

Secara terminologis, Syamsul mengutip dari Abdurrohman Mas'ud mendefinisikan pesantren adalah "the word pesantren stems from "santri" which means one who seeks Islamic knowledge. Usually the word pesantren refers to a place where the santri devotes most of his or her time to live inand acquire knowledge". Mastuhu menambahkan pesantren adalah lembaga pendidikan tradisional Islam untuk memahami, menghayati dan mengamalkan ajaran-ajaran agama Islam (tafaqquh $f i$ al-din) dengan menekankan pentingnya moral agama Islam sebagai pedoman hidup bermasyarakat sehari-hari. ${ }^{15}$

\section{b. Komponen-Komponen Pondok Pesantren}

Komponen-komponen yang terdapat pada sebuah pesantren pada umumnya terdiri dari : pondok (asrama santri), masjid, santri, pengajaran kitabkitab klasik serta Kiai. Pada pesantren-pesantren tertentu terdapat pula di dalamnya madrasah atau sekolah dengan segala kelengkapannya. Penjelasan komponen-komponen ini diuraikan lebih lanjut:16

1. Pondok

Sebuah pesantren pada dasarnya adalah suatu lembaga pendidikan yang menyediakan asrama atau pondok (pemondokan) sebagai tempat tinggal bersama sekaligus tempat belajar para santri di bawah bimbingan Kiai. Asrama untuk para santri ini berada dalam lingkungan komplek pesantren di mana Kiai beserta keluarganya bertempat tinggal serta adanya masjid sebagai tempat untuk beribadah dan tempat untuk mengaji bagi para santri. Pada pesantren yang telah maju, biasanya memiliki kompleks tersendiri yang dikelilingi oleh pagar pembatas untuk dapat mengawasi keluar masunya para santri serta untuk memisahkan dengan lingkungan sekitar. Di dalam kompleks itu diadakan pemisahan secara jelas antara perumahan Kiai dan keluarganya dengan asrama santri, baik putri maupun putra.

Pondok yang merupakan asrama bagi para santri ini merupakan ciri spesifik sebuah pesantren yang membedakannya dengan sistem pendidikan surau daerah Minangkabau. Dalam pembangunan pesantren, paling tidak terdapat empat alasan untuk para santrinya: Pertama, ketertarikan santri-santri untuk belajar kepada seorang kiai dikarenakan kemasyhuran atau kedalaman serta keluasan ilmunya yang mengharuskannya untuk menetap di kediaman Kiai itu. Kedua, kebanyakan

\footnotetext{
${ }^{15}$ Syamsul Ma'arif, Pesantren Vs Kapitalisme Sekolah, Need's Press, Semarang, 2008, hlm.62-63

${ }^{16}$ Maksum, Pola Pembelajaran di Pesantren, Departemen Agam, Jakarta, 2003, hlm 8-15
} 
pesantren adalah tumbuh dan berkembang di daerah yang jauh dari keramaian pemukiman penduduk sehingga tidak terdapat perumahan yang cukup memadai untuk menampung para santri dengan jumlah banyak. Ketiga, terdapat sikap timbal balik antara kiai dan santri yang berupa terciptanya hubungan kekerabatan seperti halnya hubungan ayah dan anak. Sikap timbal balik ini menimbulkan keakraban dan kebutuhan untuk saling berdekatan secara terus menerus dalam jangka waktu yang lama. Keempat, untuk memudahkan dalam pengawasan dan pembinaan kepada para santri secara intensif dan istiqomah. Hal ini dapat dimungkinkan jika tempat tinggal antara guru dan murid berada dalam satu lingkungan yang sama.

\section{Masjid}

Elemen penting lainnya dari pesantren adalah adanya masjid sebagi tempat yang paling tepat untuk mendidik para santri baik untuk pelaksanaan shalat lima waktu, sholat jum'at, khutnah maupun untuk pengajaran kitab-kitab kuning. Kedudukan masjid sebagai pusat pendidikan ini merupakan manifestasi universal dari sistem pendidikan Islam sebagaimana yang dilakukan oleh Rasulullah, sahabat dan orang-orang sesudahnya.

Tradisi yang diperaktekkan Rasulullah ini terus dilestarikan oleh kalangan pesantren. Para kiai selalu mengajar murid-muridnya di masjid. Mereka menganggap masjid sebagai tempat paling tepat untuk menamankan nilai-nilai kepada para santri, terutama ketaatan dan kedisiplinan. Penanaman sikap disiplin kepada para santri dilakukan melaui kegiatan shalat berjamaah setiap waktu di masjid, bangun pagi serta yang lainnya. Oleh karena itu masjid merupakan bangunan yang pertama kali dibangun sebelum didirikannya sebuah pondok pesantren.

\section{Madrasah atau sekolah}

Pada beberapa pesantren yang telah melakukan pembaharuan disamping adanya masjid sebagai tempat belajar, juga disediakan madrasah-madrasah atau sekolah sebagai tempat untuk mendalami ilmu-ilmu agama maupun ilmu-ilmu umum yang dilakukan secara klasikal. Madrasah atau sekolah ini biasanya terletak di dalam lingkungan pesantren secara terpadu.

\section{Pengajian Kitab Kuning}

Tujuan utama dari pengajaran kitab kuning adalah untuk mendidik caloncalon ulama'. Sedangkan bagi para santri yang hanya waktu singkat tinggal di pesantren maka tidak bercita-cita menjadi ulama' akan tetapi bertujuan untuk mencari pengalaman dalam hal pendalaman perasaan keagamaan.

Dalam kegiatan pembelajaran, pesantren umumnya melakukan pemisahan tempat antar pembelajaran untuk santri putra dan putri. Mereka diajar secara terpisah dan kebanyakan guru yang mengajar santri putri adalah guru laki-laki. Keadaan ini tidak berlaku untuk sebaliknya. Pada beberapa pesantren lain ada yang menyelenggarakan kegiatan pendidikannya secara bersama (co education) antara santri putra dan putrid dalam satu tempat yang sama dengan diberi hijab berupa kain atau dinding kayu. 


\section{Santri}

Santri adalah orang yang mengaji/menginap di pesantren. Secara generik santri di pesantren dapat dikelompokkan pada dua kelompok besar : santri mukim dan santri kalong. Santri mukim adalah para santri yang datang dari tempat yang jauh sehingga ia tinggal dan menetap di pondok (asrama) pesantren. Sedangkan santri kalong adalah para santri yang berasal dari wilayah sekitar pesantren sehingga mereka tidak memerlukan untuk tinggal dan menetap di pondok, mereka bolak-balik dari rumahnya masing- masing.

Santri mukim bisa juga disebut santri yang menetap, tinggal bersama kiai dan secara aktif menuntut ilmu dari seorang kiai. Dapat juga secara langsung sebagai pengurus pesantren yang ikut bertanggung jawab atas keberadaan santri lain. Setiap santri yang mukim telah lama menetap dalam pesantren secara tidak langsung bertindak sebagai wakil kiai. ${ }^{17}$

Ada dua motif seorang santri menetap sebagai santri mukim, yaitu:

a. Motif menuntut ilmu artinya santri itu datang dengan maksud menuntut ilmu dari kiainya.

b. Motif menjunjung tinggi akhlak, artinya seorang santri belajar secara tidak langsung agar santri tersebut setelah di pesantren akan memiliki akhlak yang terpuji sesuai dengan akhlak kiainya.

Pada dasarnya pesantren tidak melakukan seleksi khusus kepada calon santrinya, terutama seleksi untuk diterima atau ditolak. Para calon santri siapa saja yang datang akan diterima sebagai santri pada pesantren tersebut kapanpun ian mau sepanjang tahun karena di pesantren tidak mengenal adanya penerimaan santri baru serta tahun pelajaran baru. Hal ini berbeda dengan pesantren modern. Pesantren yang telah maju, biasanya menerapkan ketentuanketentuan sebagaimana halnya yang berlaku dalam sitem sekolah. Sehingga pada pesantren ini dikenal adanya masa penerimaan santri baru serta adanya seleksi bagi para calon santri itu serta adanya kesamaan dan keseragaman (unifikasi) waktu yang ditempuh oleh santri yang satu dengan santri yang lain pada jenjang pendidikan yang sama.

\section{Kiai dan Ustadz}

Kiai dan ustadz (asisten kiai) merupakan komponen penting yang amat mementukan keberhasilan pendidikan di pesantren. Selain itu tidak jarang kiai dan ustadz adalah pendiri dan pemilik pesantren itu atau keluarga keturunannya.

Ciri yang paling esensial bagi suatu pesantren adalah adanya seorang kiai. Kiai pada hakikatnya adalah gelar yang diberikan kepada seorang yang mempunyai Ilmu di bidang Agama dalam hal ini agama Islam. Terlepas dari anggapan kiai sebagai gelar yang sakral, maka sebutan kiai muncul di dunia pondok pesantren. Dalam tulisan ini kiai merupakan personifikasi yang sangat erat kaitannya dengan suatu pondok pesantren.

Pondok pesantren merupakan lembaga pendidikan non formal, yang khusus mempelajari pendidikan agama Islam dengan metode pembelajaran tradisional dengan mengandalkan kepemimpinan seorang kiai untuk membawa

${ }^{17}$ M Bahri Ghazali, Pesantren Berwawasan Lingkungan, CV Prasasti, Jakarta, 2003, hlm. 23 
siswa atau peserta didik kearah yang lebih baik yakni alim dalam ilmu agama dan tegaknya ajaran Islam. Sehubungan dengan keberadaan lembaga tersebut, pastilah pondok pesantren mempunyai ciri-ciri yang menunjukkan keberadaanya, adapun ciri-cirinya adalah sebagai berikut:

a. Adanya hubungan yang akrab antara santri dengan kiai

b. Kepatuhan pada kiai

c. Hidup hemat dan sederhana benar-benar diwujudkan dilingkungan pesantren.

d. Kemandirian amat terasa di pesantren

e. Jiwa tolong menolong dan suasana persaudaraan (ukhuwah islamiah sangat mewarnai pergaulan di pesantren).

f. Disiplin sangat dianjurkan.

g. Keprihatinan untuk mencapai tujuan yang mulia.

h. Pemberian ijazah ${ }^{18}$

Berdasarkan dua pendapat tentang ciri-ciri pondok pesantren di atas, dapat ditarik kesimpulan bahwa ciri-ciri pondok pesantren yang pertama merupakan ciriciri pondok pesantren yang masih tradisional (murni). Adapun tampilan pesantren pada saat ini, dengan adanya perkembangan zaman dan dinamika ilmu pengetahuan dan teknologi sudah jauh dari ciri-ciri pondok pesantren yang disebutkan di atas, dan apablia dilaksanakan dalam pendidikan saat ini tidak relevan, ciri-ciri yang ke dua pada item 2 dan 3 merupakan sebuah paradigma dan perkembangan yang baru dan menurut penulis ciri-ciri inilah yang relavan dengan pola pendidikan yang diinginkan oleh masyarakat saat ini.

\section{Tujuan Pendidikan Pesantren}

Pesantren memang unik dan setiap orang mengenal bahwa pesantren merupakan suatu sistem pendidikan klasik dan mungkin tradisional di negeri ini. Namun, melalui kebanggaan tradisionalitasnya, tidak bisa dipungkiri, justru pesantren menjadi lebih suvive (bertahan berabad-abad) bahkan dianggap sebagai alternatif di dalam glamouritas dan hegemoni modernisme yang pada saat bersamaan mencatat tradisi sebagai masalah.

Basis kekuatan eksistensial pesantren, menurut Azyumardi Azra, pada satu pihak terletak pada corak dan pada paham keislaman masyarakat Jawa itu sendiri, pada pihak lain, basis eksistensial peasantren terletak pula pada integrasi lembaga ini ke dalam struktur-struktur sosial yang ada. ${ }^{19}$

Hal yang mendominasi pendidikan pesantren bisa berkembang adalah manajemennya. Dan itu tidak lepas dari inovasi pendidikan pesantren yang tujuannya adalah meningkatkan mutu pendidikan pondok pesantren, diantaranya adalah:

a) Kurikulum, untuk memenuhi tuntutan kebutuhan santri dan masyarakat perlu dilakukan pembaharuan kurikulum pada tiga aspek penting : perencanaan, pelaksanaan dan evaluasi.

\footnotetext{
${ }^{18}$ M. Sulton Mashud, et. al., Manajemen Pondok Pesantren, Diva Pustaka, Jakarta, 2003, hlm. 45.

${ }^{19}$ Islamil SM dkk (Ed.), Dinamika Pesantren Dan Madrasah, Pustaka Pelajar, Jogyakarta,

2002, hlm. 171
} 
b) Manajemen sarana prasarana pendidikan, dan

c) Membangun jaringan kerjasama baik dengan pesantren maupun dengan lembaga lain yang terkait.

Dalam perkembangannya pondok pesantren tidaklah semata-mata tumbuh atas pola lama yang bersifat tradisional, melainkan dilakukan suatu inovasi dalam pengembangan suatu sistem. Disamping pola tradisonal yang termasuk ciri-ciri pondok-pondok salafiyah, maka gerakan pembaharuan telah memasuki derap perkembangan pondok pesantren.

Memahami tujuan pendidikan pesantren haruslah lebih dahulu memahami tujuan hidup manusia menurut Islam. Tujuan pendidikan pesantren harus sejalan dengan tujuan hidup manusia menurut Islam. Sebab pendidikan hanyalah cara yang ditempuh agar tujuan hidup itu dapat dicapai.

Al-Qur'an menegaskan, bahwa manusia diciptakan di muka bumi untuk menjadi khalifah yang berusaha melaksanakan ketaatan kepada Allah dan mengambil petunjuk-Nya dan Allah-pun menundukkan apa yang di langit dan bumi untuk mengabdi kepada kepentingan hidup manusia dan merealisasikan hidup ini. Jika tujuan hidup manusia yaitu mengembangkan pikiran manusia dan mengatur tingkah laku serta perasaannya berdasarkan Islam, dengan demikian tujuan pendidikan Islam (pesantren) adalah merealisasikan ubudiyah kepada Allah di dalam kehidupan manusia, baik individu maupun masyarakat. ${ }^{20}$

Sebagaimana kita ketahui bahwa pondok pesantren adalah suatu lembaga pendidikan swasta yang didirikan oleh perseorangan (kiai) sebagai figur central yang berdaulat menetapkan tujuan pendidikan pondoknya yang mempunyai tujuan tidak tertulis yang berbeda-beda. Tujuan tersebut kita asumsikan sebagai berikut : Tujuan khusus : "Mempersiapkan para santri untuk menjadi orang yang alim dalam ilmu agama yang dijarkan oleh kiai yang bersangkutan serta mengamalkannya dalam masyarakat". Tujuan umum: "Membimbing anak didik mejnadi manusia yang berkepribadian Islam yang sanggup dengan ilmu agamanya menjadi mubaligh Islam dalam masyarakat melalui ilmu dan amalnya".

Sedangkan tujuan pesantren sendiri oleh para wali adalah sebagai tempat menyiarkan Agama Islam dan membentuk guru-guru yang akan meneruskan usaha tersebut di kalangan umat. Dengan demikian dapat diketahui bahwa pondok pesantren sebagai lembaga pendidikan Islam semula adalah lembaga yang dipergunakan untuk penyebaran agama dan tempat mempelajari agama Islam.

\section{Analisis Data dan Pembahasan}

\section{Implementasi Entrepreneurship di Pondok Pesantren}

Kualitas sikap mental merupakan modal dasar terbesar bagi seorang untuk menjadi wirausaha, tetapi kemampuan tersebut harus ditambah dengan kemampuan manajemen (management skills) dan kemampuan untuk mengahasilkan produk (vocational skills). Kemampuan manajemen bagi semua orang dapat dipelajari, tetapi penerapan system manajemen tergantung gaya kepemimpinan seseorang. Oleh karena itu, sangat penting bagi wirausaha untuk menguasai sistem manajemen yang mencakup perencanaan, pelaksanaan,

\footnotetext{
${ }^{20}$ Abdul Munir, et.al., Rekonstruksi Pendidikan dan Tradisi Pesantren (Religiusitas Iptek), Pustaka Pelajar, Yogyakarta, 1998, hlm. 189.
} 
pengorganisasian, dan pengendalian. Selain itu, wirausaha harus memiliki kemampuan di bidang manajemen yang meliputi manajemen keuangan, personalia, produksi, dan pemasaran. Dengan demikian potensi dasar wirausaha bukan hanya kekuatan sikap mental, tetapi juga kemampuan manajerial, keterampilan dan kepemimpinan untuk berwirausaha.

Bentuk entrepreneurship di Pondok Pesantren Ma'hadul Ulum AsySyar' iyyah meliputi, toko, koperasi, tambak, warung dan rumah makan. Merupakan bentuk dari kepedulian pesantren kepada para santri agar nantinya setelah sepulang dari pesantren mendapatkan hasil dan tidak bergantung kepeda seseorang, karena di pondok sudah dibekali oleh ilmu pengetahuan yang maksimal. ${ }^{21}$

Entrepreneurship ini dapat ditimbulkan atau dibentuk pada diri seseorang melalui pendidikan atau pelatihan. Pendidikan atau pelatihan adalah proses pembelajaran konsep dan skills untuk menggali peluang- peluang yang orang lain tidak sanggup melihatnya, untuk memiliki insight, self-esteem, dan pengetahuan untuk bertindak sementara yang lain ragu-ragu. ${ }^{22}$

Proses entrepreneurship, merupakan proses yang mengandung serangkaian perbuatan santri atas dasar hubungan timbal balik yang berlangsung dalam situasi edukatif untuk mencapai tujuan tertentu. Kaitannya dengan implementasi entrepreneurship di pondok pesantren Ma'hadul Ulum Asy-Syar'iyyah Karangmangu Sarang Rembang, ada tujuan yang hendak dicapai yaitu entrepreneurship. Dalam pelaksanaan entrepreneurship ada kepengurusan yang harus dijalankan, sehingga pelaksanaannya tertata rapi, baik dari sisi manajemen dan kaderisasi. Yang bertugas yaitu : manajer, orang yang langsung ditunjuk langsung oleh kiai (pemilik), bendahara, orang yang mengelola uang, pemasukan (laba/rugi), dan lain-lain, dan karyawan, santri dan orang kepercayaan Kiai.

Pencapaian tujuan ini sangat dipengaruhi oleh sinergis antara berbagai komponen dalam proses, yang meliputi :

1) Peran Pengasuh

Pengasuh atau kiai sebagai murabbi merupakan elemen yang paling esensial dari suatu pesantren. Sudah sewajarnya bahwa pertumbuhan suatu pesantren semata-mata bergantung kepada kemampuan pribadi kiainya.

Kebanyakan pengasuh di Jawa menganggap bahwa pondok pesantren adalah diibaratkan suatu kerajaan kecil di mana kiai merupakan sumber mutlak dari kekuasaan dan kewenangan (power and authority) dalam kehidupan dan lingkungan pondok pesantren. Tidak seorangpun santri atau orang lain yang dapat melawan kekuasaan kiai (dalam lingkungan pondok pesantren ) kecuali kiai yang lebih besar pengaruhnya. Para santri selalu berfikir bahwa kiai yang dianutnya merupakan orang yang terpercaya penuh kepada dirinya sendiri (selfconfident), baik dalam hal pengetahuan Islam, maupun dalam bidang manajemen pondok pesantren.

Dalam mewujudkan entrepreneurship peran pengasuh sangat penting. Sebagaimana diketahui bahwa dalam sebuh proses haruslah melalui tahapan

\footnotetext{
${ }^{21}$ Agung Sudjatmiko, Cara Cerdas Menjadi Pengusaha Hebat, Visimedia, Jakarta, 2009

22 Jamal Ma’mur Asmani, Sekolah Entrepreneurship, Harmoni, Yogyakarta, 2011, hlm.25
} 
perencanaan, pelaksanaan dan evaluasi. Dalam proses ini tidak dapat diingkari betapa besarnya peran seorang pengasuh.

a. Peran Pengasuh dalam Perencanaan

Pelaksanaan entrepreneurship di pondok pesantren Ma'hadul Ulum AsySyar'iyyah Karangmangu Sarang Rembang di rencanakan sangat bagus sekali. Baik dari manajemen, sistem dan pelaksannan.

b. Peran Pengasuh dalam Pelaksanan

Setelah melaksanakan ketiga hal tersebut, maka peran pengasuh tidak hanya putus di jalan. Karena setiap langkah yang dilakukan santri harus di pantau agar manjadi santri yang berbasis seperti dalam pendidikan yang di terapkan tersebut .

Dalam pelaksanaan kegiatan entrepreneurship, dilakukan dengan cara sistem kerja operasional yaitu kebersamaan dan bergantian, misalnya:

- Toko mulai jam 07.00 WIB sampai jam 21.00 WIB (jam 12.00 WIB sampai jam 15.00 WIB istrirahat siang)

- Warung jam 06.00 WIB sampai jam 00.00 WIB (bergantian)

- Tambak 24 jam kerja (bergantian dengan orang kepercayaan kiyai (non santri) yang menjadi tenaga ahli.

- Jagal (penyembeliahan dan peternakan) menjadi satu usaha, jam 07.00 WIB sampai jam 17.00 WIB, bila diperlukan ada jam tambahan untuk melobi mencari sapi siap potong (di luar jam kerja).

Dalam pelaksanaan pengasuh lebih bersikap pasif melihat santrinya melakukan apapun yang ingin dilakukan. Kemudian menegur bila santri melakukan kesalahan. Sistem kerja bergantian, ketika santri bersekolah, musyawarah (ba'tsul masa'il) dan kegiatanpesantren digantikan santri yang sudah lulus. Terkadang terjadi santri yang lulus sekolah pulang (libur), santri yang bersekolah meninggalkan kegiatan pesantren dan mengantikan kerja.

\section{c. Peran Pengasuh Dalam Evaluasi}

Evaluasi dalam proses pendidikan dilakukan dalam rangka mengukur sejauh mana keberhasilan proses pendidikan yang telah dilaksanakan. Pelaksanan evaluasi dilaksanakan setiap minggu sekali.

Dalam pelaksanaan evaluasi inipun pengasuh lebih banyak bersikap pasif. Artinya, pengasuh hanya memberikan motivasi- motivasi dalam pelaksanaan kegiatan tersebut. Tanpa turun tangan langsung. Selain itu, ada juga evaluasi hal ini bertujuan untuk mengukur sejauhmana tingkat penguasaan santri dalam pendidikan tersebut.

2) Santri

Santri merupakan unsur yang penting sekali dalam perkembangan sebuah pesantren karena langkah pertama dalam tahap-tahap membangun pesantren adalah bahwa harus ada santri yang datang untuk belajar dari seorang alim. Kalau santri itu sudah menetap di rumah seorang alim, baru seorang alim itu bisa disebut kiai dan mulai membangun fasilitas yang lebih lengkap untuk pondoknya.

Santri biasanya terdiri dari dua kelompok, yaitu santri kalong dan santri mukim. Santri kalong merupakan bagian santri yang tidak menetap dalam 
pondok tetapi pulang ke rumah masing-masing sesudah selesai mengikuti suatu pelajaran di pesantren. Santri kalong biasanya berasal dari daerah-daerah sekitar pesantren jadi tidak keberatan kalau sering pergi pulang. Makna santri mukim ialah putera atau putri yang menetap dalam pondok pesantren dan biasanya berasal dari daerah jauh. Pada masa lalu, kesempatan untuk pergi dan menetap di sebuah pesantren yang jauh merupakan suatu keistimewaan untuk santri karena dia harus penuh cita-cita, memiliki keberanian yang cukup dan siap menghadapi sendiri tantangan yang akan dialaminya di pesantren.

3) Kurikulum Pendidikan

Kurikulum merupakan bagian yang paling esensial dari sebuah proses pendidikan. Pesantren sebagai intitusi pendidikan juga mempunyai formula kurikulum yang telah direncanakan dan ditentukan sejak awal berdirinya pesantren tersebut. Oleh karena itu beberapa pesantren yang telah melakukan pembaharuan kitab - kitab yang dipelajari oleh para santri tidak sepenuhnya mengambil dari kitab-kitab utama saja, melainkan disesuaikan dengan materimateri yang belum dianggap perlu dan menambahkannya dengan muatanmuatan baru berdasarkan kekhasan dan kebutuhan tertentu. Selain itu materi pembelajaran ditambah dengan ilmu-ilmu umum serta ketrampilan-ketrampilan khusus. Seperti halnya di pondok pesantren Ma'hadul Ulum Asy-Syar'iyyah Karangmangu Sarang Rembang yang santrinya di berikan modal untuk hidupnya nanti.

Melihat dari konsepsi di atas dapat disimpulkan bahwa dalam melakukan penilaian hendaknya mengarah kepada pencapaian tujuan yang diinginkan serta selalu memegang prinsip-prinsip yang berlaku, sehingga penilaian yang dilakukan yaitu terpenuhnya aspek kognisi, afeksi dan psikomotorik.

4) Media

Media disini sangat membantu untuk penerapan sebuah pendidikan. Apalagi di pondok pesantren Ma'hadul Ulum Asy- Syar'iyyah Karangmangu Sarang Rembang yang sistem pembelajaran dengan menggunakan model wirausaha atau entrepreneurship.

Dengan adanya faktor tersebut, maka implementasi pondok pesantren Ma'hadul Ulum Asy-Syar'iyyah Karangmangu Sarang Rembang sangat menonjol, yaitu :

a. Pengembangan dan penerapan dari ilmu yang didapat dari pelatihanpelatihan kewirausahaan.

b. Pengembangan bakat melalui pemasaran produk maupun pemasaran jaringan.

\section{Kendala yang Dihadapi dalam Penerapan Entrepreneurship di Pondok Pesantren}

Pesantren sebagai lembaga pendidikan yang diselenggarakan oleh masyarakat, dengan masa pengabdian yang cukup lama, tentunya tidak mudah tersingkirkan dari jalur kompetisi tersebut. Sebagai lembaga keagamaan dan keilmuan, pondok pesantren bertugas sebagai lembaga pelestari keilmuan Islam 
secara utuh, menyeluruh dan sebagai lembaga pendidikan masyarakat, pesantren bertugas menjadi kekuatan pendorong (motivator), pengarah (dinamisator) dan pembaharu (inovator) dalam kehidupan masyarakatnya. Demikian halnya dalam proses pembelajaran dan pendidikan di pondok pesantren yang menjadi objek penelitian kali ini, yang mana materi utamanya adalah pendidikan berbasis entrepreneurship. Pesantren ini selalu berusaha menjadi sebuah lembaga pendidikan agama yang selain bisa mencetak seorang agamis yang handal juga mampu mencetak kader-kader umat yang dapat memenuhi standar terbaik dalam menghadapi realitas kehidupan.

Dalam penerapan entrepreneurship di pondok pesantren Ma'hadul Ulum Asy-Syar'iyyah Karangmangu Sarang Rembang kepemilikan $100 \%$ milik keluarga kiyai, santri sebagai pelaksana. Untuk tambak sistem bagi hasil karena dibutuhkannya tenaga ahli di luar santri. Manajemen keuangan : $30 \%$ dana setoran laba, $30 \%$ untuk bisyaroh pesangon santri, dan $40 \%$ untuk modal operasional usaha.

Pondok Pesantren Ma'hadul Ulum Asy-Syar'iyyah Karangmangu Sarang Rembang adalah mempunyai kendala yang jelas, yaitu jam ngaji dan jam kerja belum terkoordinir, sehingga santri yang mengikuti (ikut) dalam entrepreurship terganggu. Dalam kendala ini, tentunya ada faktor pendorong dan penghambat dalam penerapannya, yaitu: pertama, faktor pendukung: sarana memadahi, karena dari pihak pondok pesantren sudah memberikan layanan yang memadahi, Santri termotivasi dalam untuk selalu tanggap dan aktif dalam menghadapi kehidupan, dan teknologi, dan kekuatan do'a. sedangkan faktor penghambatnya adalah : jam ngaji sama jam kerja belum diatur secara maksimal, kurangnya training dalam pembelajaran entrepreneurship, dan santri merasa bosan dan jenuh.

Realitas berbicara bahwa dampak globalisasi dan industrialisasi yang begitu merebak mengakibatkan pergeseran nilai dan orientasi masyarakat dewasa ini semakin nampak pada gaya hidup yang konsumtif, materialistis dan individualistis, sehingga jiwa keimanan sebagai moral dan akhlak, cenderung tersisihkan. Hal ini antara lain disebabkan semakin berkembangnya masyarakat ke arah masyarakat terbuka yang dengan bebas menerima dan menyerap budaya luar dan arus informasi yang masuk tidak dapat terkendali dan kurang kontrol. ${ }^{23}$

Dalam upaya penerapan pembaharuan, tentunya ada kendala yang dihadapi. Bukti-bukti menunjukkan bahwa pembaharuan banyak dilakukan akan tetapi sedikit sekali perubahan di dalam pelaksanaannya. Dalam penerapan entrepreneurship pastinya ada faktor yang mendukung dan faktor yang menghambat.

Hambatan dalam penerapan entrepreneurship, memang ada dan merupakan kejadian yang pasti dalam hal apapun, apalagi dalam proses pelaksanaan. Tetapi, juga ada faktor pendukung dalam kegiatan berlangsung. Sehingga pihak pesantren mampu menganalisa dan mengambil sesuatu pelajaran yang dianggap bagus.

Dalam hambatan ataupun pendukung tentunya dari pihak pondok sudah memperkirakan apa yang terjadi. Misalnya jika pengurus yang menjalankan wirausaha boyong, maka para santri yang bgaru menjalankan akan terasa berat bahkan tidak bisa menjalankan sesuai target. Maka dari itu Ketika santri boyong terlebih dahulu melakukan kaderisasi ketika sudah diketahui mampu

\footnotetext{
${ }^{23}$ Sulthon Masyhud, Manajemen Pondok Pesantren. Diva Pustaka, Jakarta, 2003, hlm.70.
} 
menjalankan usaha dengan baik baru meninggalkan pesantren, terkadang masih menjadi narasumber dan memantau dalam pelaksanaan wirausaha.

Adapun hasil yang didapatkan setelah santri boyong, ketika di masyarakat lebih bisa cepat adaptasi dibanding santri yang di pesantren hanya memperdalam ilmu agama, karena santri entrepreneurship ketika menjalankan usaha secara tidak langsung bersinggung dengan masyarakat serta sudah dibekali pengetahuan berwirausaha.

\section{Kesimpulan}

Dari hasil penelitian diharapkan pendidikan pesantren dapat melahirkan sumberdaya santri yang memiliki kecakapan dalam bidang ilmu-ilmu keislaman dan penguasaan teknologi secara sinergis. Hasil ini akan berimplikasi terhadap penguraian kemacetan potensi pesantren dengan kapasitasnya sebagai salah satu agents of social change. Maka dari itu penulis simpulkan bahwa:

1. Implementasi entrepreneurship di Pondok Pesantren perlu untuk dapat dibutkan konsep: menampilkan contoh (suri tauladan), pelatihan yang berkesinambungan, menciptakan lingkungan yang kondusif, dan kekuatan doa dan spiritual.

2. Kendala dalam penerapan entrepreneurship di Pondok Pesantren adalah penerapan jam /waktu pelatihan yang seringkali berbenturan dengan jam/waktu mengaji. 


\section{DAFTAR PUSTAKA}

Abdul Munir, et.al., Rekonstruksi Pendidikan dan Tradisi Pesantren (Religiusitas Iptek), Pustaka Pelajar, Yogyakarta, 1998.

Abul A'la Maududi, Manhaj Jadid Tarbiyah Wat Ta'lim, alih bahasa Judi Al-Falasani, Pembaharuan Sistem Pendidikan dan Pengajaran, CV Ramadhani, Solo, 1991.

Agung Sudjatmiko, Cara Cerdas Menjadi Pengusaha Hebat, Visimedia, Jakarta.

Anselm Strauss, et.al., Dasar-dasar Penelitian Kualitatif tata Langkah dan Tehnik-Tehnik Teoritisasi Data, Terj. M.Shodiq dan Imam Muttaqin, Pustaka Pelajar, Yogyakarta, 2003.

Arman Hakim Nasution, Entrepreneurship, Membangun Spirit Teknopreneurship, CV. ANdi Offset, Yogyakarta, 2007.

Binti Maunah, Tradisi Intelektual Santri, Teras, Yogyakarta, 2009.

Dedy Mulyana, Metologi Penelitian Kualitatif (paradigma Baru Ilmu Komunikasi dan Ilmu Sosial Lainnya, Remaja Rosdakarya, Bandung, 2004.

Departemen Agama RI, Pedoman Integrasi Pendidikan Kecakapan Hidup (Life Skills) dalam Pembelajaran, Direktorat jenderal Kelembagaan Agama Islam, Jakarta, 2005.

Dwi Swiknyo, Tarbiyah Finansial, Diva Press, Yogyakarta, 2009.

Fanstino Cardoso Gomes, Manajemen Sumber Daya Manusia. ANDI. Yogyakarta. 2003.

H.A.R. Tilaar, Paradigma Baru Pendidikan Nasional, Rhineka Cipta, Jakarta, 2000.

Islamil SM dkk (Ed.), Dinamika Pesantren Dan Madrasah, Pustaka Pelajar, Jogyakarta, 2002.

Jamal Ma'mur Asmani, Sekolah Entrepreneurship, Harmoni, Yogyakarta, 2011.

Kafrawi, Pembaharuan Sistem Pendidikan Pondok Pesantren Sebagai Usaha Peningkatan Prestasi Kerja dan Pembinaan Kesatuan Bangsa, Cemara Indah, Jakarta, 1978.

M Bahri Ghazali, Pesantren Berwawasan Lingkungan, CV Prasasti, Jakarta, 2003.

M. Arifin, Ilmu Pendidikan Islam, Bumi Aksara, Jakarta, 1996.

M. Sulton Mashud, et. al., Manajemen Pondok Pesantren, Diva Pustaka, Jakarta, 2003.

Maksum, Pola Pembelajaran di Pesantren, Departemen Agam, Jakarta, 2003

Mas'ud Machfoedz, Kewirausahaan : Metode, Manajemen dan Implementasi, BPFE, Yogyakarta, 2006. 
Mastuki, et.al., Sinergi Madrasah dan Pondok Pesantren Suatu Konsep Pengembangan Mutu Madrasah, Depag RI, 2004.

Moh Roqib, Pendidikan Islam : Pengembangan Pendidikan Integratif di Sekolah, Keluarga dan Masyarakat, PT LKis Printing Cemerlang, Yogyakarta, 2009.

Moh. Nazir, Metode Penelitian, Ghalia Indonesia, Jakarta, Cet. keempat, 1999.

Muhammad Ismail Yusnanto, Menggagas Bisnis Islami. Gema Insani, Jakarta, 2002.

Muhammad Jazuli, Tanamkan Jiwa Entrepreunership, Metro KUDUS, 2012

Mukhamad Saekan, Metodologi Penelitian Kualitatif, Nora Media Enterprise, Kudus, 2010.

Nana Sudjana, et.al., Penelitian dan Penilaian Pendidikan, Penerbit Sinar baru, Bandung, 1989.

Noeng Muhadjir, Metodologi Penelitian Kualitatif Edisi Revisi III, Rake

Sarasin, Yogyakarta, 1996.

Nur Cholis Madjid, Bilik-Bilik Pesantren Sebuah Potret Perjalanan, Paramadina, Jakarta, 1997.

Sugiyono, Memahami Penelitian Kualitatif, Alfabeta, Bandung, 2005. Sugiyono, Metode Penelitian Pendidikan - pendekatan Kualitatif, Kuantitatif, dan RED, Alfabeta, Bandung, 2010.

Suharsimi Arikunto, Prosedur Penelitian Suatu Pendekatan Praktek, PT. Rineka Cipta, Jakarta, 1993.

Sulthon Masyhud, Manajemen Pondok Pesantrenm. Diva Pustaka, Jakarta, 2003

Wahjoetomo, Perguruan Tinggi Pesantren, Cet. I, Gema Insani Pers, Jakarta, 1997.

Winardi, Entrepreneur dan Entrepreneurship, Prenada Media, Jakarta Timur, 2003.

Zamahsyari Dhofier, Tradisi Pesantren Studi tentang Pandangan Hidup Kiyai, AP3DS, Jakarta, 1984. 